\title{
The Performance of a Corruption-Suspect Candidate in Affecting the Voters Behavior of People in the Direct Election for Head of Local Government in Tulungagung 2018
}

\author{
Tri Sulistyani ${ }^{1}$, Aditya Perdana ${ }^{2}$ \\ \{ sulistyani11@gmail.com ${ }^{1}$, aditya.perdana@ui.ac.id ${ }^{2}$ \} \\ University of Indonesia, Indonesia ${ }^{1,2}$
}

\begin{abstract}
This research argues that the performance of an incumbent corruption-suspect candidate affects the voters behavior of the people. The direct election for head of local government in Tulungagung 2018 demonstrated interesting results in that the winning candidate is one that has been declared as a suspect of corruption. If in other countries such as the United States, Mexico, and Spain the status of corruption suspect on a candidate will negatively affect the candidate itself such as by reducing the number of votes, this did not occur in Tulungagung. This research tests the factor of performance of a candidate suspected of corruption in affecting the voters behavior of people in the direct election for head of local government in Tulungagung 2018. The theory using in this research was the theory of voters behavior, specifically the approach of rational choice. This research applied a quantitative method with a descriptive and inferential design, with 400 respondents as the number of samples, 95\% confidence level, and 5\% margin of error (MoE). The Findings suggest that (1) the corruption-suspect status of Syahri Mulyo did not affect the voters behavior of the Tulungagung people, only by $1.1 \%$; (2) the Tulungagung people were not rational in determining their political choices during the election, which is termed by Downs as "limited rationality" and was more affected by the factor of psychological closeness; and (3) there were external factors, being the role of patronage and clientelism, that affected the voters behavior of Tulungagung people.
\end{abstract}

Keywords: Direct election for head of local government, Corruption, Voters Behavior.

\section{Introduction}

Tulungagung Regency is one of the regencies in East Java that held direct elections in 2018. What is interesting is the direct election for head of local government in Tulungagung 2018 resulted in a unique phenomenon that is noteworthy to be examined further regarding the study of local politics in Indonesia: a candidate that had been declared as a suspect of corruption won the election. In the direct election for head of local government of 2018, there were nine regional leader candidates who were declared as suspects of corruption, but of those nine candidates, only Syahri Mulyo won the direct election for head of local government of 2018, becoming the Regent of Tulungagung. Direct election for head of local government in Tulungagung 2018 involved two pairs of candidates and their running mates, as detailed in Table 1 below: 
Table 1. Candidates of the direct election for head of local government in Tulungagung 2018

\begin{tabular}{lccc}
\hline No. & Candidate & Supporting Party & Vote \\
\hline 1 & Margiono - Eko & PKB, Demokrat, Gerindra, Hanura, & $40.03 \%$ \\
& Prisdianto & Golkar, PAN, PKS, PPP, and PBB & \multirow{2}{*}{ Syahri Mulyo -} \\
Maryoto & PDIP and Nasdem & $59.97 \%$ \\
\hline
\end{tabular}

Source: General Election Commission of Tulungagung Regency

Candidate number one, Margiono-Eko Prisdianto or popularly shortened to Mardeko, was backed by nine political parties. Margiono was the former Central Chief of the Indonesian Reporters' Association (PWI), and his running mate Eko Prisdianto is a village chief and shadow puppeteer (dalang) from Boyolangu Sub-District. Their opponents, the pair of Syahri Mulyo-Maryoto Birowo or known as Sahto, were the incumbents, backed by the PDIP and Nasdem political parties.

Exactly nineteen days before the day of the election, Syahri Mulyo was caught in a sting by the Corruption Eradication Commission (KPK) and was declared in the case of an infrastructure development and road improvement project for the Department of Public Works and Spatial Planning for Tulungagung Regency. For this case, although Syahri Mulyo had been named as a corruption suspect, he and his running mate Maryoto Birowo were still permitted to run in the direct election for head of local government to be conducted on June 27, 2018.

After the Tulungagung election was held, the Sahto pair was declared the winner after having obtained $59.97 \%$ of votes, while the Mardeko obtained $40.03 \%$. Sahto was also declared the winner of 17 sub-districts out of the 19 sub-districts in Tulungagung Regency. The phenomenon of corruption-suspect candidates does not only occur in Indonesia, but also in other countries such as the United States, Mexico, and Spain; in those countries, the naming of candidates as corruption suspects will negatively affect the candidates by reducing the number of votes for candidates or making the people reluctant to vote for them. However, this did not occur in the Tulungagung election in 2018, as the candidate that was declared as a suspect of corruption was able to win the election with an absolute majority.

According to several experts, including political analysts, the reason why the people still voted for Syahri Mulyo is the closeness of Syahri Mulyo with the people, and this capital had been built up since 2013 during his first term as a regent [1]. The people also judged that the leadership of Syahri Mulyo in the previous term was considered good, which was proven by the work programs of Sahto such as free education until middle school, massive development of infrastructure, and a healthcare program. The programs Syahri Mulyo outlined in the direct election for head of local government of 2018 included the continuing of the programs that he considered successful and deserve to be maintained, including the development of human resources through increased education [2].

\section{Research Question}

Based on the background to the problem above, the temporary hypothesis is that there is a positive influence from the performance of a corruption-suspect candidate on the voters behavior of the people in the direct election for head of local government in Tulungagung 
2018. As such, the research question is "Does the performance of a corruption-suspect candidate affect the voters behavior of the people in the 2018 Tulungagung election?".

\section{Theory and Conceptual Framework}

\subsection{Theory of Voting Behavior}

Before discussing further about voters behavior, it is important to understand about the concept of voting itself. According to Evans, voting for or electing a candidate is similar to choosing items for everyday life, but the effects are different. Choosing items for everyday life is only beneficial for a person but voting for or electing a candidate in an election has a greater impact on the lives of many people. In addition, while the selection of items is often due to individual desires, the same is not true for electing a leader, which is affected by many factors. The theory of voters behavior is divided into three approaches [3][4], which are the sociological or Columbian approach, the psychological or American approach, and rational choice. However, based on the existing problems, this research using the rational choice approach, because this approach is significantly prominent in affecting the voters behavior of people in the Tulungagung election in 2018.

Downs [5] defines rationality as an effort to achieve certain goals in a reasonable manner, in that in making a vote, a person bases the selection on the best knowledge of that person, with the least amount of resources. In other words, a person who is rational, in desiring to realize something that the person wants, will prefer it to be with as minimal costs as possible. Downs also stated that a rational voter is a selfish voter who only fulfills the interests of the voter, and if not, will prioritize own interests above the interests of many other people. In the context of voters behavior, a rational voter will vote for a party or candidate that promises the most benefits for the voter. Further, rational voters are not too interested with the concept of politics, but more on the benefits to be gained. Downs describes this as "utility maximization" [4]

In general, a rational voter is one who considers benefits and losses [6][5]. Here, "benefits" refer to those that will be gained in the future, and thus Downs states that rational voters are voters who think about the government in the future; when voters ignore this, they can be considered irrational. The theory of Downs also includes a term for voters who have "limited rationality", or voters who make political decisions only based on an evaluation of the leadership of the previous candidate. Although this has been based on the calculation of benefits and losses, this is considered "limited rationality" because the decision is not based on sufficient and extensive information.

\section{Conceptual Framework}

In Indonesia, the breakthrough study on voters behavior was performed by Clifford Geertz who examined socio-religious orientation patterns (santri, abangan, and priyayi) [7]. However, a study by Liddle and Mujani found that the polarization of ideology politics no longer affected voters behavior in the 2004 election [8]; Rubaidi [9] also found that ideology politics, specifically in Java, is fading or no longer evident because the people make their votes by rational choice and calculate benefits and losses materially to determine their political choices. This is evident in the 2014 election, where voters were more affected by the benefits 
they gain through vote buying and other forms of patronage, compared to influence from ideology politics or other forms of loyalty.

The elections in Solok and North Minahasa in 2015 also showed that the people were rational in making their votes. The 2015 elections in Solok and North Minahasa also showed the same phenomenon, where former corruption convicts won the elections. In Solok, the status of Gusmal as a former corruption convict was not a problem for the people; this is because the people judged that the leadership of Gusmal as a regional chief led to many achievements [10]. Meanwhile, in North Minahasa, the victory of Vonny Anneke Panambuan, who was also a former corruption convict, is due to several sociological factors that affected voting, such as gender, age, and education. Based on psychological factors, figure and issue orientation were more dominant in affecting voting compared to party identification. Voters in North Minahasa also were indicated to be rational, because although they were given essential goods and items, this did not affect their votes [11].

In other countries, such as through the research of Peters and Welch [12] it was found in the United States that the House of Representatives elections from 1968-1978 showed a reduction of votes toward corrupt candidates, but this was not too significant, by only $6-11 \%$. The reduction of votes is because the voters were able to see the severity level of the cases. Yet on the other hand, corruption is only one of the factors considered by rational voters. If the corruption incurred by a candidate is considered small and the goodness and achievement of the candidate is more noticeable by voters, the issue of corruption will be ignored or rationalized.

Welch and Hibbing [12] stated that incumbent candidates who are hit by cases of corruption will experience a reduction of votes by $25 \%$ or even higher compared to incumbents not affected by cases of corruption. As in the United States, in Spain, candidates who are convicted of corruption at the local level will also experience negative effects such as loss of votes by up to $14 \%$, which will increase if the information becomes widely publicized in the media. In this case, the media has a role in affecting voters [13]. Meanwhile, in Catalonia, Muñoz Anduiza and Gallego proved that the reason corrupt candidates still manage to win elections is because of implicit exchange and information credibility. Here, implicit exchange means that there is good performance that allows for the issue of corruption to be ignored, while information credibility means that accusations from the opponent lack credibility [14].

\section{Research Method}

This research is using the quantitative method, in order to see the relationship of causality between the dependent variable and independent variable [15]. The utilized technique for data collection is by conducting direct and structured interviews using a questionnaire as the instrument. The population is the people of Tulungagung Regency who have possessed the right to vote (being 17 years of age or older). The obtained sample was 400 respondents with a margin of error (MoE) of 5\% and confidence level of 95\%. The utilized sampling technique was Multistage Random Sampling because the sample was determined through several stages, by determining samples in 19 sub-districts by a random number, then at the hamlet level, at the RT level, and finally using gender. The collected data were then processed using SPSS (Statistical Package for the Social Sciences) and analyzed using descriptive and inferential statistics 


\section{Findings and Analysis}

As explained above, Syahri Mulyo was the only corruption-suspect candidate for regional chiefs who was able to win the 2018 elections. Based on the tabulation of survey results, out of 400 respondents, $86.50 \%$ respondents knew about the status of Syahri Mulyo as a suspect of corruption, $12.50 \%$ did not know, and $1 \%$ of respondents did not answer.

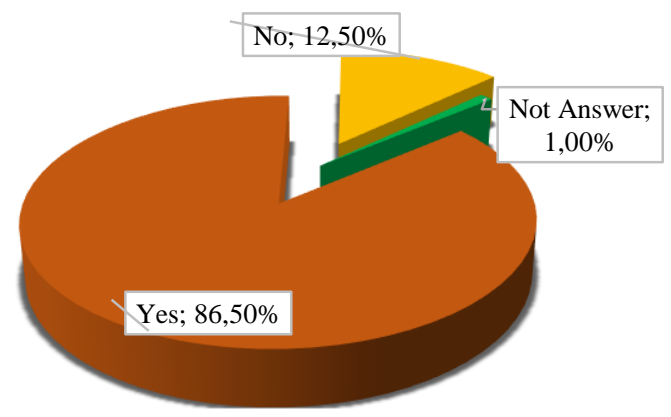

Figure 1. Awareness of Respondents toward the Corruption Case of Syahri Mulyo Source: Tabulation of Survey Results

From the above chart, it can be seen that a majority of respondents knew the information about the corruption case that involves Syahri Mulyo being named as a suspect. However, the information did not affect the people in voting for the candidate due to several reasons, which are detailed in Table 2.

Table 2. Reasons for Voting for Candidates

\begin{tabular}{|l|c|c|c|}
\hline & $\begin{array}{c}\text { Margiono-Eko } \\
\text { Prisdianto }\end{array}$ & $\begin{array}{c}\text { Syahri Mulyo- } \\
\text { Maryoto Birowo }\end{array}$ & $\begin{array}{c}\text { Not known/no } \\
\text { response }\end{array}$ \\
\hline $\begin{array}{l}\text { Attracted by the figure of the } \\
\text { regent candidate }\end{array}$ & 34.4 & 34.5 & 4.4 \\
\hline Interested with the work programs & 23.3 & 20.1 & 31.1 \\
\hline The candidate is well-known & 15.6 & 14.4 & 4.4 \\
\hline $\begin{array}{l}\text { The candidate and running mate } \\
\text { are good people and helpful to } \\
\text { residents }\end{array}$ & 8.9 & 5.3 & 4.4 \\
\hline $\begin{array}{l}\text { Attracted by the figure of the vice- } \\
\text { regent candidate }\end{array}$ & 22.2 & 6.8 & \\
\hline $\begin{array}{l}\text { The candidate and running mate } \\
\text { often conduct campaigns }\end{array}$ & 5.6 & 5.7 & 11.1 \\
\hline Attracted by the backing parties & 2.2 & & \\
\hline
\end{tabular}




\begin{tabular}{|l|c|c|c|}
\hline Mobilized by other people & $\cdot$ & 0.4 & $\cdot$ \\
\hline $\begin{array}{l}\text { The other candidate is involved in } \\
\text { corruption }\end{array}$ & 1.1 & $\cdot$ & $\cdot$ \\
\hline Candidate performance is known & $\cdot$ & 0.4 & $\cdot$ \\
\hline Did not answer & 1.1 & 0.4 & 37.8 \\
\hline \multicolumn{1}{|c|}{ Total Respondents } & $\mathbf{9 0}$ & $\mathbf{2 6 4}$ & $\mathbf{4 5}$ \\
\hline
\end{tabular}

Source: Tabulation of Survey Results.

From Table 3, it can be seen that the status of Syahri Mulyo as a corruption suspect did not affect the people in electing the candidate; only $1.1 \%$ of respondents said they voted for Mardeko because the opposing candidate was involved in a corruption case. The figures of the regent candidates, both Margiono and Syahri Mulyo, had a strong influence in affecting the voters behavior of the people, compared to the vice-regent candidates. Out of the 90 respondents who voted for Mardeko, 34.4\% answered because they were attracted to the figure of the regent candidate, Margiono. Meanwhile, of the 264 respondents who voted for Sahto, 34.5\% stated that they liked the figure of Syahri Mulyo. The above data also showed the reason why the people still voted for Syahri Mulyo, who had been named as a corruption suspect before the day of the election, which is because the figure of Syahri Mulyo is attractive to the people.

The work programs of the candidates also became one of the factors of consideration in voting. If the candidate work programs are judged to be appropriate to what the people desire, the people will consider the programs and vice versa. Based on the tabulation of survey results, $23 \%$ of respondents voted for Mardeko because they liked the work programs that were offered by the candidate pair. Only $20.1 \%$ voted for Sahto because they liked their work programs. As such, it can be said that the work programs offered by the candidates also had an influence on the electability of each of the candidates.

From the results of the survey, it can also be seen that party identification in the direct election for head of local government in Tulungagung did not affect voters much. Seen in detail, voters who were still loyal to political parties were those that voted for Sahto than Mardeko by $5.7 \%$ and $2.2 \%$. This is reasonable, considering that Tulungagung is a base region for PDIP. However, in the direct election for head of local government of 2018, the candidate figure had a greater influence compared to party identification.

In the 2013 direct election for head of local government, the victory of Sahto was due to the role of the botoh [16]. Further, the father of Syahri Mulyo, who among the people is known as "Mbah Dasar", openly confirmed this matter. However, conversely, in the direct election for head of local government of 2018, the people who said they voted for Sahto because they were mobilized other people only amounted to 0.4 percent. The mobilization in this case is taken to mean that there is a role of the botoh in affecting the votes of the people. Thus, it can be said that the role of the botoh is still present, but the role is not as major as it was in the 2013 election. Another view states that the victory of Sahto is due to the role of volunteers. The volunteers consist of the cadres of the backing parties of PDIP and Nasdem, as well as those of the greater public, who organized themselves. The number of these volunteers even exceeded those in the party-based victory team. There were 12,800 witnesses for the volunteers, while there were only 3,000 for the parties. During the election, the team of 
volunteers also played a role in determining campaign teams by presenting the ways that Sahto had succeeded in the previous term. The head of the PDIP faction, Suharminto or popularly known as "Bedut", had an important role in the victory of Sahto in the 2018 election [17].

In addition to the role of the botoh, the direct election for head of local government in Tulungagung 2018 was also marked by money politics. From the results of cross-tabulation, $15.65 \%$ out of 400 respondents had answered that they had been offered both cash and items by the candidates.

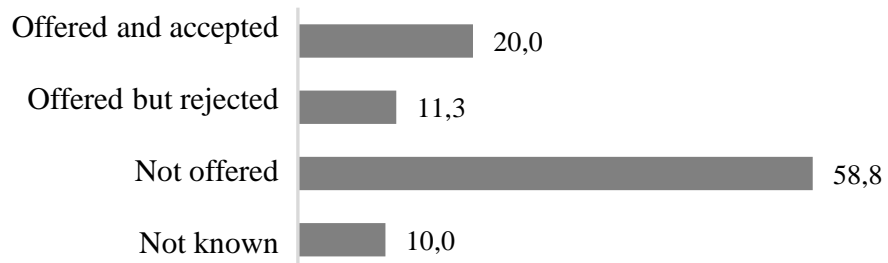

Figure 2. Offers of Money Politics in the direct election for head of local government in Tulungagung 2018.

Source: Tabulation of Survey Results

From Figure 2, it can be seen that money politics affected the people in the direct election for head of local government in Tulungagung 2018. What is meant by money politics is not only about cash but also items or services in other forms. Of the respondents, $20 \%$ stated that they were offered, and they received the offers, while $11.3 \%$ stated that they were offered but rejected the offers. However, those who answered that they were never offered was quite high at $58.8 \%$, and those who stated they did not know amounted to $10 \%$. Out of the 400 respondents, 12 respondents stated they were offered by Mardeko and 59 respondents were offered by Syahri Mulyo.

Table 4. Offers of Money Politics from the Candidates

\begin{tabular}{|l|c|c|}
\hline \multicolumn{1}{|c|}{ Candidate } & Margiono-Eko Prisdianto & Syahri Mulyo-Maryoto Birowo \\
\hline Accepted and voted for & $61.5 \%$ & $88.1 \%$ \\
\hline Accepted but did not vote for & $15.4 \%$ & $8.5 \%$ \\
\hline Did not answer & $23.1 \%$ & $3.4 \%$ \\
\hline Number of Respondents & 13 & 59 \\
\hline
\end{tabular}

Seen from the number of respondents who received offers from money politics, there were more recipients from the Sahto pair than those who received offers from the Mardeko pair. The number of respondents who received from and voted for Sahto was also quite high at $88.1 \%$, while those who received from and voted for Mardeko was $61.5 \%$. This indicates that the team of Sahto put greater efforts into money politics compared to the team of Mardeko. The massive efforts that went into money politics by the team of Sahto was another strategy to attain victory and cover up the status Syahri Mulyo as a corruption suspect. Meanwhile, the Mardeko team did not put massive efforts into money politics for the reason that the status of 
the opposing candidate as a corruption suspect could be used as its own strategy to persuade the people.

In addition to several of the factors above, in making their votes, the people also conducted evaluation of the candidate performance in the previous term, specifically the Sahto pair as the incumbent. A majority of the people judged that the leadership of Sahto in the 2013-2018 term was good; it led to many achievements and developments particularly in infrastructure, education, economy, and healthcare. As such, out of 400 respondents, 50.3\% had stated that the leadership of Sahto in the previous term was satisfactory.

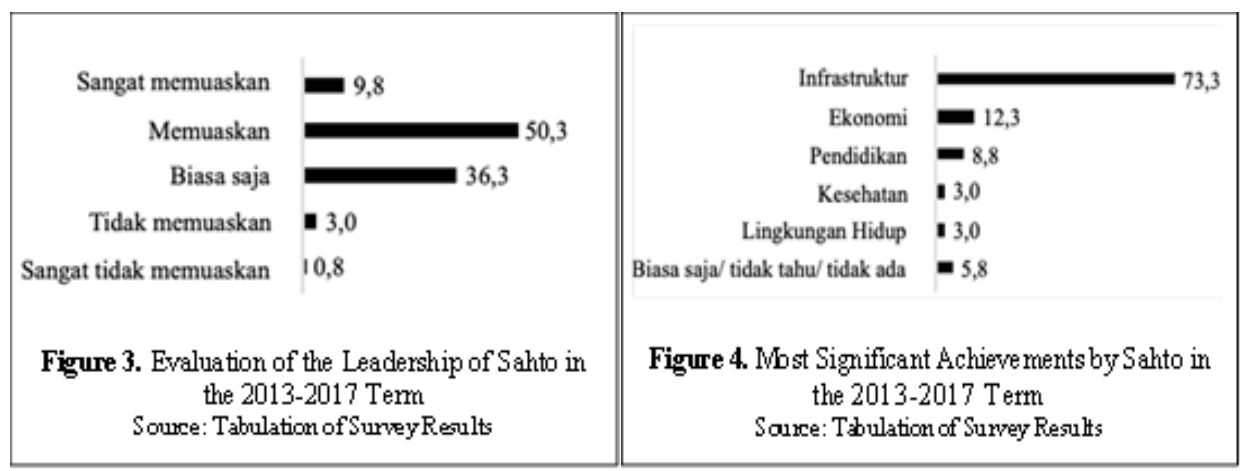

In the context of direct election for head of local government, evaluation of each candidate has an effect on the political choices of the people. Particularly for the incumbent, if the people judged the previous term to be positive, then this will also have positive effects during the election. In the direct election for head of local government in Tulungagung 2018, though Syahri Mulyo had been declared as a suspect of corruption, this had no negative effects. The people of Tulungagung were not affected by the corruption case, because in making their votes, the people examined the accomplishments of Syahri Mulyo himself. This was proven by the fact that 60.1 percent of the people were satisfied with the leadership of Syahri Mulyo-Maryoto Birowo from 2013-2018. The development of infrastructure is the work program that was most considered successful by the people, followed by the economy and education. In education, the performance of Sahto was considered to have positive effects. Many people were pleased with the programs of Sahto in education because the people felt that they were helpful, such as free schooling from elementary school to middle school, free school uniforms, and free transportation to school.

The Sahto pair as the incumbent also desired to continue the work programs that were considered successful for the development of Tulungagung, and thus considering the work programs in the direct election for head of local government of 2018, the work programs of Sahto were more appropriate to the situation or desires from the Tulungagung people. The status of Sahto as the incumbent was beneficial because it became its own strategy for a repeat victory against the opposing candidate of Margiono-Eko Prisdianto.

Of the 400 respondents, the three most-stated answers on the development priorities that the people desired were for education, employment opportunities, and infrastructure. These programs became the primary programs of Sahto in economy and public service. 


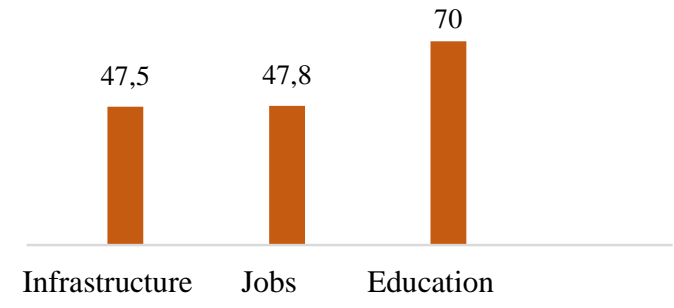

Figure 5. Development Priority as Chosen by the People. Source: Tabulation of Survey Results.

Although the people judged education to be one of the programs of Sahto that was considered to be successful from the previous term, in reality, education is still an issue among the Tulungagung people. Based on data from the Central Statistics Agency [18], formal education in Tulungagung is still minimal; this is due to several factors such as educational facilities, economy, and family. Aside from education, employment opportunities are also an important issue that must be managed by the government. In 2015 , the open unemployment rate was 4.1 percent, which includes people of working age that have not found or still looking for employment. The rate of open unemployment in 2017 fell to 2.3 percent. From 2013 to 2017 the regent and vice-regent of Tulungagung at the time was Syahri Mulyo and Maryoto Birowo, and thus it can be said that the leadership of Sahto was able to reduce the rate of unemployment, though not significantly. The re-election of Sahto indicated that the people were still expecting their leadership to continue and they ignored the status of Syahri Mulyo as a suspect of corruption.

From the findings above, it can be seen that the status of Syahri Mulyo as a suspect did not affect the people, but there were other factors such as performance evaluation. Before making their votes, the people conducted an evaluation of the performance of the candidates. If this is considered positive, then this leads to good results in the form of a re-election by the people, and if this is considered negative, then the people will not re-elect the candidate. In the direct election for head of local government in Tulungagung 2018, the people evaluated the leadership of Sahto from the previous term, which led to a positive judgment and the people re-electing the 'candidate, despite the status of Syahri Mulyo as a corruption suspect.

\section{Conclusion}

From this research, it can be concluded that the status of Syahri Mulyo as a corruption suspect did not much affect the people in the direct election for head of local government, only by $1.1 \%$. In making their political decisions, the people of Tulungagung were not rational, or what is termed by Downs as having "limited rationality", only basing their decisions on a performance evaluation of the previous candidate without considering broadly available information and the negative effect of corruption in the future. In making their votes, the people also still consider the emotional bonds with or psychological closeness to a candidate. Thus, it can be concluded that the hypothesis in this research is rejected, in that the performance of a corruption-suspect candidate did not affect the voters behavior of the people in the direct election for head of local government in Tulungagung 2018 
In addition, the direct election for head of local government in Tulungagung 2018 was also still affected by external factors such as the role of botoh and money politics, although not significantly. Thus, the results of this research affirms that the political elite is not a product of rational society, but a product of patronage and clientelism. The limitation of this research is that only the approach of rational choice was used for examination, and thus further research is expected to discover other factors that affected the people in voting for a corruption suspect in the direct election for head of local government in Tulungagung 2018.

\section{References}

[1] L. Rahardian, “'Syahri Mulyo: Tahanan KPK yang Menang PilbupTulungagung,.” [Online]. Available: Tirto.id,. [Accessed: 29-Jun-2018].

[2] Surya.co.id, "Dinilai Sukses Mengembangkan Lingkungan Berkesinambungan, Tulungagung Ukir Prestasi Tingkat Asean," 13-Sep-2017. .

[3] L. M. Bartels, "“The Study of Electoral Behavior Forthcoming (in much-abbreviated form) in," Oxford Handb. Am. Elections Polit. Behav., no. 1987, 2008.

[4] D. Roth, "Studi Pemilu Empiris: Sumber, Teori-teori, Instrumen dan Metode," Jakarta Für Die Freiheit, 2008.

[5] A. Downs, "An economic theory of political action in a democracy," J. Polit. Econ., vol. 65, no. 2, pp. 135-150, 1957.

[6] J. Scott, "Rational choice theory," Underst. Contemp. Soc. Theor. Present, vol. 129, pp. 671$685,2000$.

[7] A. Gaffar, "'Javanese Voters: A Case Study of Election Under a Hegemonic Party System (Doctoral dissertation, The Ohio State University.," 1988.

[8] R. W. Liddle and S. Mujani, "Leadership, party, and religion: Explaining voting behavior in Indonesia," Comp. Polit. Stud., vol. 40, no. 7, pp. 832-857, 2007.

[9] Rubaidi, “Jawa Timur: Klientelisme Baru dan Pudarnya Politik Aliran. Dalam Politik Uang di Indonesia: Patronase dan Klientelisme pada Pemilu Legislatif 2014,'” E. Aspinall M. Sukmajati, 2015.

[10] F. N. Rezki, "Perilaku Memilih Masyarakat Dalam Pilkada Kabupaten Solok Tahun 2015." Universitas Andalas, 2018.

[11] D. E. Mopeng, "Perilaku Pemilih pada Pemilihan Kepala Daerah Minahasa Utara Periode 20162021 (Studi di Desa Sawangan Kecamatan Airmadidi)," J. Polit., vol. 1, no. 7, 2015.

[12] S. Welch and J. R. Hibbing, "The effects of charges of corruption on voting behavior in congressional elections, 1982-1990," J. Polit., vol. 59, no. 1, pp. 226-239, 1997.

[13] E. Costas-Pérez, A. Solé-Ollé, and P. Sorribas-Navarro, "Corruption scandals, voter information, and accountability," Eur. J. Polit. Econ., vol. 28, no. 4, pp. 469-484, 2012.

[14] J. Muñoz, E. Anduiza, and A. Gallego, "Why do voters forgive corrupt mayors? Implicit exchange, credibility of information and clean alternatives," Local Gov. Stud., vol. 42, no. 4, pp. 598-615, 2016.

[15] J. W. Creswel, "Research design: Qualitative, quantitative, and mixed methods approaches," Los angeles Univ. Nebraska-Lincoln, 2009.

[16] P. Hergianasari, "MATINYA MESIN PARTAI POLITIK (Studi Kasus Pencalonan Syahri Mulyo dalam Pilkada Kabupaten Tulungagung 2013)," Cakrawala, vol. 5, no. 2, 2016.

[17] K. Endri, “'Ditahan KPK, Ini Rahasia Kemenangan Calon Bupati Tulungagung,."” [Online]. Available: pilkada.tempo.co,. [Accessed: 28-Jun-2018].

[18] BPS Kabupaten Tulungagung, "Angka Partisipasi Sekolah Menurut Kelompok Usia Sekolah,” 2018. 
